\title{
Universitas
}

Review of

Muhammadiyah Purwokerto

\section{ANALISIS FAKTOR- FAKTOR FINANCIAL DISTRESS FOOD AND BAVERAGE'S} COMPANIES

\author{
Putri Dewi Permatasari*, Totok Susilo Pamuji Nugroho
}

Affiliation:

Accounting Department, STIE Atma

Bhakti Surakarta, Indonesia

\section{* Correspondence:}

putridewi.permatasari30@gmail.com

\section{Article Process:}

Submitted:

September 19, 2021

Reviewed:

September 27, 2021

Revised:

October 2, 2021

Accepted:

October 9, 2021

Published:

October 10, 2021

\section{Citation:}

Permatasari, P. D., \& Nugroho, T. S. P., (2021). Analisis Faktor- Faktor Financial Distress Food And Baverage's Companies. RAAR: Review of Applied Accounting Research, 1(2), 143-153.

\section{Office Address:}

Jl. K.H. Ahmad Dahlan, Dukuhwaluh, Kec. Kembaran,

Kabupaten Banyumas, Jawa

Tengah 53182

e-ISSN : 2807-8969

\begin{abstract}
ABSTRAK
Penelitian ini bertujuan untuk menguji pengaruh profitabilitas, likuiditas, leverage dan rasio pertumbuhan terhadap financial distress. pada perusahaan makanan dan minuman yang terdaftar di Bursa Efek Indonesia tahun 2018 dan 2019. Jenis penelitian ini adalah kuantitatif. Populasi dalam penelitian ini adalah perusahaan makanan dan minuman yang terdaftar di Bursa Efek Indonesia tahun 2018 dan 2019. Sampel dalam penelitian ini menggunakan metode purposive sampling dan diperoleh 10 perusahaan makanan dan minuman yang sesuai dengan kriteria yang telah ditentukan. Teknik analisis data yang digunakan adalah analisis regresi berganda dengan program SPSS 16.0. Hasil penelitian menunjukkan bahwa variabel likuiditas dan rasio pertumbuhan tidak berpengaruh terhadap financial distress. Sedangkan variabel profitabilitas dan leverage berpengaruh terhadap financial distress.
\end{abstract}

Kata Kunci: Profitabilitas, Likuiditas, Leverage, Growth Ratio dan Financial Distress.

\section{ABSTRACT}

This study examines the effect of profitability, liquidity, leverage, and growth ratio on financial distress, in food and beverage companies listed on the Indonesia Stock Exchange in 2018 and 2019. This research is quantitative research which consists of food and beverage companies listed on the Indonesia Stock Exchange in 2018 and 2019. The sample in this study used the purposive sampling method and obtained ten food and beverage companies that matched the predetermined criteria. The data analysis technique used is multiple regression analysis with SPSS 16.0 program. The results showed that the liquidity and growth ratio variables did not affect financial distress. In comparison, the profitability and leverage variables affect financial distress.

Keywords: Profitability, Liquidity, Leverage, Growth Ratio, and Financial Distress. 


\section{PENDAHULUAN}

Semakin berkembangnya usaha saat ini menyebabkan semakin menimbulkan persaingan yang sangat ketat. Setiap perusahaan didirikan untuk memperoleh laba guna menjaga konsistensinya dalam dunia industri (Wahyuningsih dan Suryanawa, 2012). Dalam suatu dunia industri jika terdapat perusahaan yang tidak bisa bersaing maka perusahaan tersebut akan terjadi permasalahan financial distress. Faktor yang dapat menyebabkan financial distress misalnya adalah kekurangan modal dan beban utang yang cukup besar sehingga dapat menyebabkan kerugian (Afriyeni, 2012).

Perusahaan yang mengalami suatu gejala financial distress akan menimbulkan banyak kerugian bagi karyawan, pemegang saham maupun perekonomian negara (Al-Khatib dan Al-Horani, 2012; Azizah dan Nurcahyani, 2020). Oleh karena itu suatu perusahaan industri harus bisa memprediksi kondisi perusahaan dimasa yang akan datang. Dalam mengembangkan usahanya suatu perusahaan memerlukan banyak dana, maka dari itu perusahaan harus pandai mencari sumber dana untuk kelancaran usahanya. Menurut Rohmadini et al (2018) pendanaan yang besar akan menyebabkan perusahaan tersebut mengalami kesulitan keuangan dan apabila tidak diatur dengan benar maka perusahaan bisa terjadi financial distress.

Financial distress yaitu penurunan kondisi keuangan secara signifikan sehingga memungkinkan adanya kebangkrutan untuk kedepannya (Platt dan Platt, 2002). Model financial distress harus dikembangkan karena dengan mengetahui kondisi keuangan perusahaan sejak dini maka perusahaan dapat melakukan tindakan dengan cepat untuk mengantisipasi terjadinya kebangkrutan dan bisa menghindari kerugian dalam nilai investasi (Almilia dan Kristijadi, 2003). Financial distress dapat dilihat dan diukur dari laporan keuangan suatu perusahaan dengan cara menganalisis laporan keuangan tersebut. Dalam penelitian ini financial distress diukur menggunakan model Altman Z-Score. Model Altman Z-Score dinyatakan dalam bentuk persamaan linear yang terdiri dari 5 koefisien yang mewakili rasio keuangan tertentu (Fahmi, 2014:135-137). Pada penelitian ini terdapat beberapa rasio keuangan yang digunakan perusahaan untuk memprediksi financial distress, diantaranya adalah profitabilitas, likuiditas, leverage dan growth ratio.

Indikator kinerja keuangan pertama dalam penelitian ini yaitu profitabilitas. Dalam penelitian ini rasio profitabilitas diukur dengan Return On Assets (ROA). Putu et al (2019) menyatakan bahwa Return On Asset mempunyai pengaruh negatif terhadap financial distress. Sedangkan Christine (2019) menyatakan bahwa Return On Asset berpengaruh positif dan signifikan terhadap financial distress. Indikator kinerja keuangan kedua yaitu likuiditas. Likuiditas diukur dengan menggunakan current ratio, merupakan rasio yang membagi jumlah aset lancar dengan hutang lancar suatu perusahaan (Widhiari dan Merkusiwati, 2015). Penelitian likuiditas dilakukan Putu et al (2019) yang menyatakan bahwa current ratio berpengaruh negatif terhadap financial distress. Sedangkan Agustini dan Wirawati (2019) menyatakan bahwa likuiditas tidak memiliki pengaruh terhadap financial distress.

Indikator kinerja keuangan selanjutnya yaitu leverage. Rasio leverage diukur dengan Debt to Asset Ratio (DAR). Penelitian tentang leverage dilakukan oleh (Christine, 2019) dengan hasil bahwa leverage mempunyai pengaruh negatif terhadap financial distress. Sedangkan Aisyah et al (2017) dan Putu et al (2019) menyatakan bahwa leverage tidak mempunyai pengaruh terhadap financial distress. Indikator kinerja keuangan yang terakhir yaitu growth ratio. Penelitian mengenai growth ratio dilakukan oleh (Farah, 2018) dan (Fitri dan Dillak, 2020) yang menunjukkan bahwa sales growth tidak mempunyai pengaruh terhadap financial distress.

\section{TINJAUAN PUSTAKA DAN PENGEMBANGAN HIPOTESIS}

\section{Financial Distress.}

Platt dan Platt (2002) menyatakan bahwa financial distress yaitu penurunan kondisi keuangan suatu perusahaan, yang terjadi sebelum perusahaan mengalami bangkrut atau likuidasi. Financial distress 
merupakan ketidakmampuan perusahaan dalam membayar kewajiban jangka pendek maupun kewajiban jangka panjang pada saat jatuh tempo, sehingga dapat menyebabkan perusahaan mengalami bangkrut, Darsono dan Ashari (2005). Sedangkan Gamayuni (2011) menjelaskan bahwa financial distress sebagai keadaan kesulitan keuangan yang menyebabkan awal terjadinya kebangkrutan.

\section{Profitabilitas.}

Rasio Profitabilitas adalah rasio keuangan untuk mengetahui kemampuan perusahaan dalam memperoleh keuntungan dari pendapatan yang terkait dengan penjualan, aset, dan ekuitas perusahaan berdasarkan pengukuran tertentu, Setiawan (2021). Sedangkan Gill (2003:36) dalam Setiawan (2021) berpendapat bahwa rasio profitabilitas digunakan untuk mengukur dan membantu mengendalikan pendapatan, dengan cara memperbesar penjualan, memperbesar margin dan mendapatkan manfaat yang lebih besar dari pengeluaran biaya-biaya. Aisyah et al (2017) menyatakan bahwa profitabilitas mempunyai pengaruh negatif terhadap financial distress. Hasil penelitian ini diperkuat oleh Agustini dan Wirawati (2019) dan Setiyawan (2020). Berbeda dengan penelitian Rohmadini et al (2018) yang menyatakan bahwa profitabilitas tidak berpengaruh terhadap financial distress. Peneliti sejalan dengan penelitian Setiyawan (2020), ketika Return On Asset besar maka kinerja keuangan suatu perusahaan semakin baik karena tingkat kembalian semakin besar, sehingga resiko suatu perusahaan mengalami financial distress juga semakin kecil. Berdasarkan paparan diatas maka dapat diajukan hipotesis sebagai berikut :

\section{$\boldsymbol{H}_{1}$ : Rasio profitabilitas mempunyai pengaruh terhadap financial distress pada perusahaan food and beverage di BEI.}

\section{Likuiditas.}

Likuiditas yaitu kemampuan perusahaan untuk memenuhi semua kewajiban keuangan yang telah jatuh tempo. Fahmi $\{2012: 174\}$ menjelaskan bahwa likuiditas yaitu kemampuan suatu perusahaan untuk memenuhi kewajiban jangka pendek dengan tepat waktu. Likuiditas perusahaan memiliki fungsi dan manfaat tersendiri bagi proses operasi perusahaan. Aisyah et al (2017) melakukan penelitian dengan hasil bahwa rasio likuiditas tidak mempunyai pengaruh terhadap financial distress. Diperkuat oleh penelitian yang dilakukan Agustini dan Wirawati (2019) dan Rohmadini et al (2018). Berbeda dengan penelitian Setiyawan (2020) dengan hasil bahwa likuiditas mempunyai pengaruh negatif terhadap financial distress. Peneliti sejalan dengan penelitian Setiyawan (2020), Apabila perusahaan memiliki prosentase CR yang tinggi maka perusahaan tersebut tidak mengalami financial distress. Berdasarkan paparan diatas maka dapat diajukan hipotesis sebagai berikut :

$\boldsymbol{H}_{2}$ : Rasio likuiditas mempunyai pengaruh terhadap financial distress pada perusahaan food and beverage di BEI.

\section{Leverage.}

Menurut Harahap (2013), leverage adalah suatu rasio keuangan yang menggambarkan hubungan utang perusahaan terhadap modal, dimana rasio tersebut untuk melihat seberapa jauh suatu perusahaan dibiayai oleh hutang. Menurut Fahmi (2012), leverage yaitu ukuran yang digunakan perusahaan untuk menganalisis laporan keuangan agar dapat memperlihatkan besarnya jaminan untuk kreditor. Christine (2019) melakukan penelitian yang menjelaskan bahwa rasio leverage mempengaruhi financial distress. Penelitian tersebut diperkuat oleh penelitian Agustini dan Wirawati (2019) dan Rohmadini et al (2018) yang menjelaskan bahwa rasio leverage mempunyai pengaruh positif dan signifikan terhadap financial distress. Berbeda dengan penelitian yang dilakukan oleh Aisyah (2017), Saputra dan Salim (2020) dan Setiyawan (2020) yang menjelaskan bahwa leverage tidak mempunyai pengaruh terhadap financial distress. Peneliti ini sejalan dengan penelitian Christine (2019), apabila semakin besar kegiatan suatu perusahaan yang dibiayai oleh hutang maka akan semakin besar juga perusahaan tersebut mengalami financial distress, hal 
tersebut terjadi karena semakin besar kewajiban perusahaan membayar hutang. Berdasarkan paparan diatas maka dapat diajukan hipotesis sebagai berikut:

$\boldsymbol{H}_{3}$ : Rasio leverage mempunyai pengaruh terhadap financial distress pada perusahaan food and beverage di BEI.

\section{Growth Ratio.}

Menurut Kasmir (2012:107) Rasio pertumbuhan yaitu rasio keuangan yang menggambarkan kemampuan suatu perusahaan untuk tetap mempertahankan ekonominya di tengah pertumbuhan perekonomian. Sedangkan Hardiyanti (2012:4) berpendapat bahwa Rasio pertumbuhan digunakan untuk mengukur kemampuan perusahaan dalam mempertahankan ekonominya di bidang industri tempat perusahaan beroperasi. Yudiawati dan Indriani (2016) melakukan penelitian dengan hasil bahwa growth ratio mempunyai pengaruh negatif dan signifikan terhadap financial distress. Berbeda dengan penelitian yang dilakukan Agustini dan Wirawati (2019), Saputra dan Salim (2020) yang menyatakan bahwa growth ratio tidak berpengaruh terhadap financial distress. Peneliti sepakat dengan penelitian Yudiawati dan Indriani (2016), rasio pertumbuhan penjualan dapat mempengaruhi financial distress suatu perusahaan. Apabila pertumbuhan penjualan suatu perusahaan meningkat maka perusahaan tidak akan mengalami financial distress. Berdasarkan paparan diatas maka dapat diajukan hipotesis sebagai berikut :

$\boldsymbol{H}_{4}$ : Growth ratio mempunyai pengaruh terhadap financial distress pada perusahaan food and beverage di BEI.

\section{Framework}

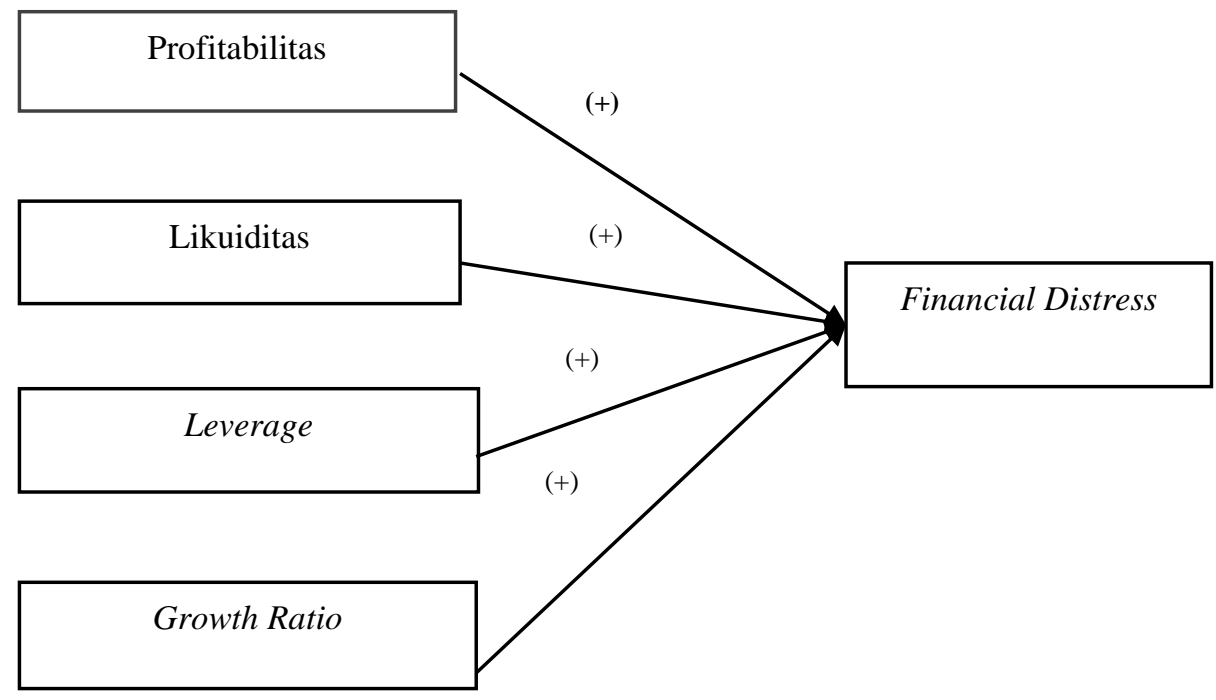

\section{METODE PENELITIAN}

Penelitian ini menggunakan jenis data dokumenter. Data yang digunakan merupakan data kuantitatif yang diukur dengan menggunakan skala numeric. Sumber data pada penelitian ini adalah data sekunder yang diperoleh dari laporan keuangan tahunan perusahaan manufaktur sub sektor food and beverage pada tahun 2018 dan 2019 yang diperoleh dan diunduh melalui website www.idx.co.id. Diakses tanggal 10 Mei 2021. Populasi yang digunakan dalam penelitian ini yaitu seluruh perusahaan manufaktur sub sektor food and beverage yang terdaftar di Bursa Efek Indonesia pada tahun 2018 dan 2019. Teknik pengambilan sampel yang digunakan pada penelitian ini adalah purposive sampling, dengan kriteria pemilihan sampel sebagai berikut :

\section{RAAR}

Vol.1 No.2 
1. Perusahaan manufaktur sub sektor food and beverage yang terdaftar di Bursa Efek Indonesia periode 2018 dan 2019.

147 2. Perusahaan tidak memiliki laba negatif atau rugi selama tahun 2018 dan 2019.

3. Perusahaan tidak mengalami penurunan penjualan selama tahun 2018 dan 2019.

4. Perusahaan yang selalu melaporkan laporan keuangannya pada tahun penelitian.

Dari kriteria pemilihan sampel di atas maka diperoleh sampel sebanyak 10 perusahaan, yaitu :

Tabel 1. Daftar Sampel Perusahaan Food and Beverage

\begin{tabular}{|l|c|l|}
\hline No & Kode Perusahaan & \multicolumn{1}{c|}{ Nama Perusahaan } \\
\hline 1 & CAMP & Campina Ice Cream Industry Tbk, PT \\
\hline 2 & CLEO & Sariguna Primatirta Tbk, PT \\
\hline 3 & COCO & Wahana Interfood Nusantara Tbk, PT \\
\hline 4 & DLTA & Delta Djakarta Tbk, PT \\
\hline 5 & FOOD & Sentra Food Indonesia Tbk, PT \\
\hline 6 & GOOD & Garudafood Putra Putri Jaya Tbk, PT \\
\hline 7 & HOKI & Buyung Poetra Sembada Tbk, PT \\
\hline 8 & ICBP & Indofood CBP Sukses Makmur Tbk, PT \\
\hline 9 & INDF & Indofood Sukses Makmur Tbk, PT \\
\hline 10 & SKBM & Sekar Bumi Tbk, PT \\
\hline
\end{tabular}

Sumber : Data yang Diolah, 2021.

Penelitian ini menggunakan variabel dependen financial distress. Financial distress diukur dengan menggunakan model Z-score yang dikembangkan oleh Altman pada tahun 1968. Menurut Yi, W (2012). Model Z-score merupakan satu model yang paling sering digunakan untuk mengetahui indikasi adanya financial distress. Z-score untuk perusahaan manufaktur dihitung dengan rumus sebagai berikut:

$Z$-score $=0.717 X_{1}+0.847 X_{2}+3.107 X_{3}+0.420 X_{4}+0.998 X_{5}$

Keterangan:

$\mathrm{X}_{1}=$ Modal Kerja Bersih/Total Aset

$\mathrm{X}_{2}=$ Saldo Laba/Total Aset

$\mathrm{X}_{3}=$ Laba Kotor/Total Aset

$\mathrm{X}_{4}=$ Total Modal/Total Utang

$\mathrm{X}_{5}=$ Penjualan/Total Aset

Klasifikasi perusahaan yang sehat dan perusahaan yang tidak sehat berdasarkan hasil perhitungan Z-score :

Z-score $<1,23$

Z-score $>2,90$

\section{RAAR}

Vol.1 No.2
Z-score $>1,23$ dan $<2,90$
$=$ Abu-abu

Penelitian ini menggunakan variabel independen yang meliputi profitabilitas, likuiditas, leverage dan growth ratio yang dapat dijelaskan dibawah ini : 


\section{Profitabilitas}

Murhadi (2013) mendefinisikan profitabilitas dengan Return On Asset sebagai rasio keuangan yang menggambarkan kemampuan perusahaan untuk menghasilkan laba. Rumus untuk menghitung Return On Asset adalah :

$$
\text { ROA }=\frac{\text { Laba Bersih }}{\text { Total Aset }}
$$

\section{Likuiditas}

Hery (2015:166) menjelaskan bahwa rasio likuiditas dengan current ratio merupakan rasio keuangan yang menggambarkan kemampuan perusahaan dalam memenuhi semua kewajiban jangka pendeknya yang akan jatuh tempo.

Rumus untuk menghitung current ratio sebagai berikut :

$$
\text { current ratio }=\frac{\text { Aktiva Lancar }}{\text { Kewajiban Lancar }}
$$

\section{Leverage}

Salalahi et al., (2018), menjelaskan bahwa rasio leverage yaitu rasio keuangan yang menunjukkan kemampuan perusahaan dalam memenuhi kewajiban jangka panjangnya. Pemakaian Debt to Total Asset Ratio digunakan untuk mengukur berapa besar total aktiva perusahaan yang dibiayai oleh kreditur. Rumus untuk menghitung Debt to Total Asset Ratio adalah :

$$
\text { DAR }=\frac{\text { Total Utang }}{\text { Total Aktiva }}
$$

\section{Growth Ratio}

Kasmir (2012:107), menyatakan bahwa Growth Ratio yaitu rasio keuangan yang menggambarkan kemampuan suatu perusahaan untuk mempertahankan posisi ekonominya di tengah pertumbuhan perekonomian. Rumus untuk menghitung growth ratio adalah :

Growth rate $=\frac{\begin{array}{l}\text { penjualan saat ini }- \text { penjualan } \\ \text { sebelumnya }\end{array}}{\text { penjualan sebelumnya }} \times 100 \%$

\section{HASIL}

\section{Pengujian Data.}

Dari empat uji asumsi klasik yang dilakukan dalam penelitian ini, hasil pengujian menunjukkan hasil uji asumsi klasik lolos semua.

\section{Pengujian Hipotesis.}

Tabel dibawah menunjukkan ringkasan hasil uji regresi dengan metode analisis regresi linier berganda untuk pengujian hipotesis. Berdasarkan Tabel dibawah, hasil uji $\mathrm{F}$, uji t dan uji $\mathrm{R}^{2}$ atas persamaan regresi penelitian menunjukkan : 
Tabel 2. Uji Parsial (t)

Coefficients $^{\mathrm{a}}$

\begin{tabular}{|c|c|c|c|c|c|c|}
\hline \multirow{2}{*}{\multicolumn{2}{|c|}{ Model }} & \multicolumn{2}{|c|}{$\begin{array}{l}\text { Unstandardized } \\
\text { Coefficients }\end{array}$} & \multirow{2}{*}{\begin{tabular}{|l} 
Standardized \\
Coefficients
\end{tabular}} & \multirow[b]{2}{*}{$t$} & \multirow[b]{2}{*}{ Sig. } \\
\hline & & B & Std. Error & & & \\
\hline \multirow[t]{5}{*}{1} & (Constant) & .929 & .233 & & 3.992 & .001 \\
\hline & ROA & 11.386 & 2.803 & .562 & 4.061 & .001 \\
\hline & Rasio Lancar & -.063 & .091 & -.095 & -.687 & .502 \\
\hline & DAR & .362 & .049 & 608 & 7.360 & .000 \\
\hline & Growth Ratio & -1.036 & .859 & -.091 & -1.206 & .246 \\
\hline
\end{tabular}

Sumber : Data Sekunder yang diolah, 2021.

Berdasarkan tabel 2 di atas maka dapat diketahui tingkat signifikansi dari variabel independen yang diuji :

a. Pengaruh Profitabilitas (ROA) terhadap Financial Distress.

Berdasarkan hasil uji statistik, dihasilkan nilai signifikansi sebesar 0,001 . Nilai signifikansi $0,001<0,05$ maka $\mathrm{H}_{1}$ diterima. Sehingga, dapat disimpulkan bahwa profitabiitas mempunyai pengaruh signifikan terhadap financial distress.

b. Pengaruh Likuiditas (Rasio Lancar) terhadap Financial Distress.

Berdasarkan hasil uji statistik, dihasilkan nilai signifikansi sebesar 0,502. Nilai signifikansi $0,502>0,05$ maka $\mathrm{H}_{2}$ ditolak. Sehingga, dapat disimpulkan bahwa likuiditas tidak mempunyai pengaruh signifikan terhadap financial distress.

c. Pengaruh Leverage (DAR) terhadap Financial Distress.

Berdasarkan hasil uji statistik, dihasilkan nilai signifikansi sebesar 0,000. Nilai signifikansi $0,000<0,05$ maka $\mathrm{H}_{3}$ diterima. Sehingga, dapat disimpulkan bahwa leverage mempunyai pengaruh signifikan terhadap financial distress.

d. Pengaruh Growth Ratio terhadap Financial Distress.

Berdasarkan hasil uji statistik, dihasilkan nilai signifikansi sebesar 0,246. Nilai signifikansi $0,246>0,05$ maka $\mathrm{H}_{4}$ ditolak. Sehingga, dapat disimpulkan bahwa growth ratio tidak mempunyai pengaruh signifikan terhadap financial distress.

Tabel 3. Uji Simultan (F)

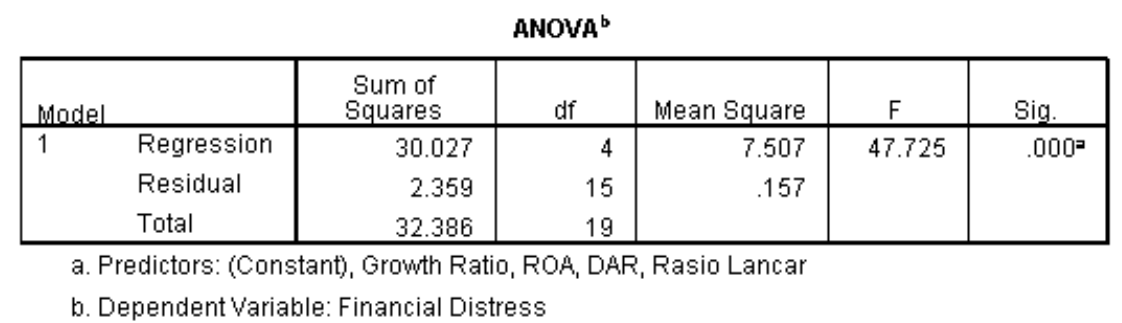

Sumber : Data yang Diolah, 2021.

RAAR

Vol.1 No.2

Berdasarkan hasil dari output spss pada tabel 3 diperoleh nilai $\mathrm{F}$ hitung sebesar 47,725 dengan tingkat signifikansi sebesar 0,000 . Nilai $F$ tabel adalah df $1=4$ dan df $2=15$, sehingga diperoleh nilai $F$ tabel sebesar 3,06. Dari hasil diatas dapat diartikan F hitung 47,725 > F tabel 3,06 dan siginifkansi sebesar $0,000<0,05$, sehingga diperoleh kesimpulan bahwa variabel profitabilitas (ROA), likuiditas (Rasio Lancar), leverage (DAR), dan growth ratio secara simultan mempengaruhi variabel financial distress dan hipotesis alterbatif $\left(\mathrm{H}_{\mathrm{a}}\right)$ diterima. 
Tabel 4. Hasil Uji Koefisien Determinasi $\left(\mathrm{R}^{2}\right)$

\begin{tabular}{|l}
\begin{tabular}{|l|c|c|c|c|c|}
\hline Mode & Rodel Summary \\
\hline 1 & $.963^{2}$ & R Square & $\begin{array}{c}\text { Adjusted R } \\
\text { Square }\end{array}$ & $\begin{array}{c}\text { Std. Error of } \\
\text { the Estimate }\end{array}$ & $\begin{array}{c}\text { Durbin- } \\
\text { Watson }\end{array}$ \\
\hline
\end{tabular} \\
a. Predictors: (Constant), Growth Ratio, ROA, DAR, Rasio Lancar \\
b. Dependent Variable: Financial Distress
\end{tabular}

Sumber : Data yang Diolah, 2021.

Berdasarkan hasil dari output spss pada tabel 4 diatas dapat diketahui besarnya koefisien determinasi (Adjusted $\mathrm{R}^{2}$ ) adalah 0,908 atau 90,8\%. Dari hasil tersebut menunjukkan bahwa variabel independen dapat menjelaskan variabel dependen financial distress sebesar $90,8 \%$ dan sisanya sebesar 9,2\% dapat dijelaskan oleh variabel lain yang tidak termasuk dalam model penelitian.

\section{PEMBAHASAN}

\section{Pengaruh Profitabilitas terhadap Financial Distress.}

Hasil penelitian ini menunjukkan bahwa variabel profitabilitas mempunyai pengaruh terhadap financial distress. Hal ini dapat dilihat dari nilai signifikansi profitabilitas sebesar 0,001 $<0,05$, sehingga dapat diperoleh kesimpulan bahwa $\mathrm{H}_{1}$ diterima. Hasil ini tidak sesuai dengan penelitian yang dilakukan oleh Rohmadini et al., (2018) yang menjelaskan bahwa profitabilitas tidak mempunyai pengaruh terhadap financial distress. Hasil penelitian ini sesuai dengan penelitian Saputra dan Salim (2020) dan Nugraha dan Nursito (2021) yang menjelaskan bahwa profitabilitas mempunyai pengaruh terhadap financial distress. Rasio profitabilitas yang tinggi menunjukkan kemampuan suatu perusahaan dalam menggunakan dan mengelola semua aset yang dimilikinya secara efektif dan efisien untuk memperoleh keuntungan sehingga dapat mengurangi biaya yang dikeluarkan oleh perusahaan.

\section{Pengaruh Likuiditas terhadap Financial Distress}

Berdasarkan hasil pengujian yang disajikan, hasil penelitian ini menjelaskan bahwa variabel likuiditas tidak mempunyai pengaruh terhadap financial distress. Hal ini dapat dilihat dari nilai signifikansi likuiditas sebesar 0,502 >0,05, sehingga diperoleh kesimpulan bahwa $\mathrm{H}_{2}$ ditolak. Hasil penelitian ini tidak sesuai dengan penelitian Setiyawan (2020) yang menjelaskan bahwa likuiditas mempunyai pengaruh terhadap financial distress. Hasil penelitian ini sesuai dengan penelitian yang dilakukan oleh Rohmadini (2018), Agustini dan Wirawati (2019), Aisyah et al., (2017) dan Nugraha (2021) yang menjelaskan bahwa rasio likuiditas tidak mempunyai pengaruh terhadap financial distress. Tidak berpengaruhnya rasio likuiditas disebabkan karena perusahaan pada sampel penelitian dikatakan mampu untuk mendanai operasional perusahaan dalam memenuhi semua kewajiban jangka pendek yang dimilikinya. Menurut Dewi dan Dana (2017) tingkat rasio likuiditas perusahaan tidak dapat menjamin suatu perusahaan akan mengalami financial distress pada penelitian ini, karena current ratio merupakan rumus untuk mengukur likuiditas jangka pendek, sedangkan financial distress merupakan prediksi untuk jangka panjang. Semakin tingginya current ratio tidak bisa menjamin tingkat penurunan financial distress sehingga potensi financial distress pada suatu perusahaan akan semakin rendah.

\section{Pengaruh Leverage terhadap Financial Distress}

Berdasarkan hasil pengujian yang disajikan, hasil penelitian ini menyatakan bahwa variabel leverage mempunyai pengaruh terhadap financial distress. Hal ini dapat dilihat dari nilai signifikansi leverage sebesar 0,000 <0,05, sehingga diperoleh kesimpulan bahwa $\mathrm{H}_{3}$ diterima. Hasil penelitian ini tidak sesuai dengan penelitian yang dilakukan Setiawan (2020), Aisyah et 
al., (2017) dan Saputra dan Salim (2020) yang menyatakan bahwa leverage tidak mempunyai pengaruh terhadap financial distress. Hasil penelitian ini sesuai dengan penelitian yang dilakukan oleh Christine (2019), Agustini dan Wirawati (2019) dan Rohmadini (2018) yang menjelaskan bahwa rasio leverage mempunyai pengaruh terhadap financial distress. Semakin besar rasio leverage suatu perusahaan maka akan menyebabkan semakin besar juga risiko suatu perusahaan mengalami kesulitan keuangan untuk melunasi pokok pinjaman dan beban bunga yang disebabkan total aset yang dimiliki perusahaan tidak bisa menjamin hutang-hutangnya.

\section{Pengaruh Growth Ratio terhadap Financial Distress}

Berdasarkan hasil pengujian yang disajikan, hasil penelitian menjelaskan bahwa variabel growth ratio tidak mempunyai pengaruh terhadap financial distress. Hal ini dilihat dari nilai signifikansi growth ratio sebesar 0,246 > 0,05, sehingga diperoleh kesimpulan bahwa $\mathrm{H}_{4}$ ditolak. Penelitian yang dilakukan Yudiawati dan Indriani (2016) tidak sesuai dengan hasil penelitian ini yang menjelaskan bahwa growth ratio mempunyai pengaruh terhadap financial distress. Hasil penelitian ini sesuai dengan penelitian yang dilakukan oleh Saputra (2020), Agustini dan Wirawati (2019) yang menjelaskan bahwa growth ratio tidak mempunyai pengaruh terhadap financial distress. Dapat diartikan bahwa menurunnya growth ratio belum tentu membuat suatu perusahaan mengalami financial distress. Hal tersebut disebabkan karena suatu perusahaan memperoleh pinjaman yang bisa digunakan untuk menanggung semua beban perusahaan apabila terjadi penurunan penjualan atau ketidak stabilan penjualan.

\section{KESIMPULAN}

Penelitian ini mempunyai tujuan untuk melihat pengaruh profitabilitas, likuiditas, leverage dan growth ratio terhadap financial distress. Berdasarkan hasil analisis data di atas maka dapat diambil kesimpulan sebagai berikut :

1. Variabel profitabilitas mempunyai pengaruh positif terhadap financial distress pada perusahaan manufaktur sub sektor food and beverage yang terdaftar di Bursa Efek Indonesia pada tahun 2018 dan 2019.

2. Variabel likuiditas tidak mempunyai pengaruh terhadap financial distress pada perusahaan manufaktur sub sektor food and beverage yang terdaftar di Bursa Efek Indonesia pada tahun 2018 dan 2019.

3. Variabel leverage mempunyai pengaruh positif terhadap financial distress pada perusahaan manufaktur sub sektor food and beverage yang terdaftar di Bursa Efek Indonesia pada tahun 2018 dan 2019.

4. Variabel growth ratio tidak mempunyai pengaruh terhadap financial distress pada perusahaan manufaktur sub sektor food and beverage yang terdaftar di Bursa Efek Indonesia pada tahun 2018 dan 2019.Berdasarkan kesimpulan yang sudah disampaikan, maka peneliti memberikan

Saran yang dapat digunakan untuk mengembangkan penelitian bagi peneliti selanjutnya :

1. Bagi penelitian selanjutnya diharapkan bisa menambah jumlah sampel dan periode penelitian.

2. Untuk penelitian selanjutnya diharapkan bisa menambah beberapa variabel yang berkaitan dengan financial distress.

3. Penelitian selanjutnya dapat menggunakan rumus lain untuk mengukur masing-masing variabel independen.

\section{REFERENSI}

Afriyeni, E. 2012. Model Prediksi Financial Distress Perusahaan. Jurnal Polibisnis. Volume 4 No. 2 ISSN 1858-3717, 4(2) : 1-10. Perusahaan Ritel yang Terdaftar di Bursa Efek Indonesia (BEI). E-Jurnal Akuntansi. 26(1) : 251-280. 
Aisyah, N. N., F. T. Kristanti, dan D. Zultilisna. 2017. Pengaruh Rasio Likuiditas, Rasio Aktivitas, Rasio Profitabilitas, dan Rasio Leverage Terhadap Financial Distress. e-Proceeding of Management, 4(1).

Al-khatib, H. B, dan A. Al-Horani. 2012. Predicting Financial Distress of Public Companies Listed in Amman Stock Exchange. European Scientific Journal, 8(15):1-17. http://dx.doi.org/10.19044/esj.2012.v8n15p\%25p

Almilia, L.S dan Kristijadi. 2003. Analisis Rasio Keuangan untuk Memprediksi Kondisi Financial Distress Perusahaan Manufaktur yang Terdaftar di BEI. Jurnal Akuntansi dan Auditing Indonesia. 7(2) : 183-210.

Azizah, S. N., \& Nurcahyani, Y. (2020). Corporate Governance Index, Corporate Ownership Structure and Audit Committee on Debt Costs. Muhammadiyah Riau Accounting and Business Journal, 1(2), 072-080.

Christine, D. 2019. Pengaruh Profitabilitas, Leverage, Total Arus Kas dan Ukuran Perusahaan terhadap Financial Distress pada Perusahaan Property dan Real Estate yang Terdaftar di Bursa Efek Indonesia Tahun 2014-2017. Jurnal Ekonomi dan Ekonomi Syariah, 2(2).

Dewi, N. K. T. S, dan I. M. Dana. 2017. Pengaruh Growth Opportunity, Likuiditas, Non-Debt Tax Shield dan Fixed Asset Ratio Terhadap Struktur Modal. E-Jurnal Riset Manajemen Unud, Vol. 6 No.2, 772-801.

Fahmi, I. 2014. Analisis Laporan Keuangan. Bandung. Alfabeta.

Farah, I. 2018. Pengaruh Likuiditas, Leverage, Profitabilitas, Aktivitas, dan Sales Growth dalam Memprediksi, Terjadinya Financial Distress menggunakan Discriminant Analysis dan Logistic Regression. Jakarta.

Fitri, M. A, dan V. J. Dillak. 2020. Arus Kas Operasi, Leverage, Sales Growth terhadap Financial Distress. Jurnal Riset Akuntansi Kontemporer, 12(2).

Ghozali, I. 2011. Aplikasi Analisis Multivariate Dengan Program SPSS. Semarang: Badan Penerbit Universitas Diponegoro.

Hery, T. A. 2015. Analisis Laporan Keuangan. Yogyakarta: CAPS.

Kasmir. 2012. Analisis Laporan Keuangan. Jakarta: PT. Raja Grafindo Persada.

Muhardi, W. R. 2013. Analisi Laporan Keuangan : Proyeksi dan Valuasi Saham. Jakarta : Penerbit Salemba Empat.

Nugraha, D. A, dan N. Nursito. 2021. Pengaruh Current Ratio, Debt To Equity Ratio, dan Return On Equity Terhadap Financial Distress. COSTING: Journal of Economic, Business and Accounting, 4(2) : 591-600.

Platt, H, dan M. B. Platt. 2002. Predicting Corporate Financial Distress: Reflections on ChoiceBased Sample Bias. Journal of Economics and Finance, 26(2).

Putu, N. L., I. D. Made, dan I. P. Edy. 2019. Pengaruh Rasio Likuiditas, Rasio Leverage dan Rasio Profitabilitas terhadap Financial Distress pada Perusahaan Manufaktur. Kumpulan Hasil Riset Mahasiswa Akuntansi (KHARISMA), 1(1).

Rohmadini, A., M. Saifi, dan A. Darmawan. 2018. Pengaruh Profitabilitas, Likuiditas dan Leverage. Jurnal Administrasi Bisnis, 61(2) : 12. 
Salalahi, H. R. D, F. T. Kristanti, dan M. Muslih. 2018. Pengaruh Rasio Keuangan dan Ukuran Perusahaan Terhadap Kondisi Kesulitan Keuangan (Financial Distress) Pada Perusahaan Sub-Sektor Transportasi yang Terdaftar di Bursa Efek (BEI) Periode 2013-2016. eProceeding of Management : Vol.5, No.1 ISSN : 2355-9357.

Saputra, A. J, dan S. Salim. 2020. Pengaruh Profitabilitas, Leverage, Firm Size, dan Sales Growth terhadap Financial Distress. Jurnal Paradigma Akuntansi, 2(1) : 262-269.

Setiyawan, E. 2020. Pengaruh Struktur Kepemilikan, Profitabilitas, Likuiditas, Leverage dan Nilai Tukar terhadap Financial Distress pada Perusahaan yang Terdaftar di IDX Tahun 20162017. Jurnal Ilmu Manajemen (JIM), 8(1).

Wahyuningsih, N, dan I. K. Suryanawa. 2012. Analisis Pengaruh Opini Audit. Jurnal Akuntansi dan Bisnis, 7(1).

Widhiari, N. L. M. A, dan N. K. L. A. Merkusiwati. 2015. Pengaruh Rasio Likuiditas, Leverage, Operating Capacity, dan Sales Growth Terhadap Financial Distress. E-Jurnal Akuntansi Universitas Udayana, 11(2) : 456- 469.

Yi, W. 2012. Z-score Model on Financial Crisis Early-Warning of Listed Real Estate Companies in China: a Financial Engineering Perspective. Systems Engineering Procedia, 3.

Yudiawati, R, dan A. Indriani. 2016. Analisis Pengaruh Current Ratio, Debt to Total Asset Ratio, Total Asset Turnover, dan Sales Growth Ratio terhadap Kondisi Financial Distress (Studi Kasus Pada Perusahaan Manufaktur yang Terdaftar di BEI Tahun 2012-2014). Diponegoro Journal of Management, 5(2). 